\title{
Foreign Investor Flows and Sovereign Bond Yields in Advanced Economies
}

\author{
Serkan Arslanalp ${ }^{1}$ \\ International Monetary Fund, USA \\ sarslanalp@imf.org \\ Tigran Poghosyan \\ International Monetary Fund, USA \\ tpoghosyan@imf.org
}

Received: 11 January 2016 / Revised: 28 April 2016 / Accepted: 25 May 2016 / Published online: 16 June 2016

\begin{abstract}
Asset allocation decisions of international investors are at the core of capital flows. This paper explores the impact of these decisions on long-term government bond yields, using a quarterly investor base dataset for 22 advanced economies over 2004-2012. We find that a one percentage point increase in the share of government debt held by foreign investors can explain a 6-10 basis point reduction in long-term sovereign bond yields over the sample period. Accordingly, international flows to core advanced economy bond markets over 2008-12 are estimated to have reduced 10-year government bond yields by 40-65 basis points in Germany, 20-30 basis points in the U.K., and 35-60 basis points in the U.S. In contrast, foreign outflows are estimated to have raised 10-year government bond yields by $40-70$ basis points in Italy and 110-180 basis points in Spain during the same period. These results suggest that changes in the foreign investor base for sovereign debt can have economically and statistically significant effects on sovereign bond yields, independent of other standard macroeconomic determinants of bond yields.
\end{abstract}

JEL classification: E4, E6, G1.

Keywords: Government bond yields, investor base, interest rate determinants.

\section{INTRODUCTION}

The divergence in long-term sovereign bond yields experienced by advanced economies in the aftermath of the global financial crisis has featured prominently in policy discussions over the last several years (IMF 2011, IMF 2012a, IMF 2012b). On the one hand, long-term yields in core advanced economies are perceived to be below their fundamental value, which is commonly attributed to the quantitative easing policies pursued by the central banks. On the other hand, sovereign bond yields in a number of euro area countries are perceived to be above their fundamental level due to capital outflows and elevated perceptions of tail risks.

The purpose of this paper is to analyze the factors driving the divergence in sovereign bond yields among advanced economies (AEs) from the perspective of foreign investor decisions.

Corresponding author: International Monetary Fund, 700 19th Street, N.W., Washington, D.C. 20431, USA. Tel: +1 (202) 623-5420, SArslanalp@imf.org

The views expressed in this paper are those of the authors and do not necessarily represent the views of the IMF, its Executive Board, or IMF management. 
While we acknowledge the importance of fundamental macroeconomic, monetary, and fiscal policy determinants for explaining the dynamics of long-term sovereign bond yields in AEs, we focus our analysis on the impact of the foreign investor base (FIB) of sovereign debt, which has received less attention in cross-country studies and policy discussions. ${ }^{2}$

In particular, we argue that shifts in the foreign investor base observed in AEs in the aftermath of the global financial crisis have contributed to the diverging movements in long-term sovereign bond yields observed through end-2012. More specifically, foreign inflows to the United States, the United Kingdom, and core euro area countries have put downward pressure on sovereign bond yields, while foreign outflows have resulted in upward pressure in the periphery euro area countries. ${ }^{3}$

In order to analyze the impact of the FIB on long-term sovereign bond yields, we utilize a comprehensive dataset on the holders of government debt compiled by Arslanalp and Tsuda (2014). This dataset contains quarterly information on the composition of government debt over 2004-2012 for 22 advanced economies. We focus our attention on the FIB, including whether the investors represent foreign official or foreign private investors.

Our analysis suggests that:

- A rising foreign share of government debt holdings is associated with a statistically and economically significant decline in long-term sovereign bond yields. On average, a one percentage point increase in the share of general government debt held by non-residents can explain a $6-10$ basis point decrease in 10-year sovereign bond yields.

- The type of foreign investors also matters. The impact of official foreign investors on long-term sovereign bond yields is slightly smaller ( 7 basis points) compared to that of foreign private investors ( 8.5 basis points). However, the difference in coefficients is not statistically significant.

- The increase in the FIB in the aftermath of the global financial crisis contributed to a decline in the long-term sovereign bond yields in the United States, the United Kingdom, and Germany of 35-60, 20-30, and 40-65 basis points, respectively. By contrast, the decline in the FIB in the aftermath of the global financial crisis contributed to an increase in the long-term sovereign bond yields in Spain and Italy of 110-180 and 40-70 basis points, respectively.

Our results have several implications. They suggest that "normalization" of macroeconomic, monetary, and fiscal policy determinants of bond yields may be insufficient to bring long-term rates back to their pre-crisis level unless this is accompanied by a similar "normalization" of the FIB. To the extent that the current benchmark portfolio allocations by foreign investors are distorted by "safe-haven" considerations and that these portfolio allocations can be persistent, our analysis suggests that the currently observed divergence in long-term sovereign bond yields in advanced economies may continue in the foreseeable future.

The remainder of the paper is structured as follows. Section II reviews the existing literature, with a focus on the foreign investor base as a determinant of sovereign bond yields. Section III describes the methodology employed in the analysis. Section IV describes the data and provides descriptive statistics. Section V presents the empirical findings, and the last section concludes with some policy implications.

\section{LITERATURE REVIEW}

On February 16, 2005, Federal Reserve Chairman Alan Greenspan described in a congressional testimony the recent behavior of long-term U.S. Treasury yields as a "conundrum." Specifically, he was referring to the atypical situation in the middle of 2004 when, despite monetary tightening,

2 The importance of the investor base for the sustainability of public debt in market access countries has been emphasized in the recently revised IMF staff guidance note on debt sustainability (IMF, 2013b).

Following the 2013 Article IV report for the euro area, periphery countries include Greece, Ireland, Italy, Portugal, and Spain. 
the Treasury yields continued their decline and were fluctuating at levels well below what one would expect on the basis of economic fundamentals (inflation, growth, fiscal and monetary policy stances). A number of follow-up academic studies have shown that a possible cause of the conundrum was the structural change in the investor base of U.S. Treasury securities, with the expansion in foreign demand for U.S. bonds (especially from Asia) depressing the long rates by tens of basis points (e.g., Bernanke, 2005). Moreover, it seems that the conundrum was not limited to the United States only, but applied to euro area countries as well around the same period (e.g., Hördahl, Tristani, and Vestin, 2006).

Foreign purchases of government debt could lead to a decline in bond yields for a number of reasons. First, a foreign purchase of an asset is, by definition, a capital inflow. And capital inflows, all else equal, can reduce the cost of funding for domestic borrowers to the extent that they expand the domestic savings pool available for domestic borrowers (i.e., as long as capital inflows are not offset by capital outflows one-for-one). Second, financial integration, driven by a desire for portfolio diversification by global investors and an expanding pool of world savings, increase cross-border flows; as a result, foreign inflows can lead to a convergence in real interest rates. Finally, foreign investors may have a higher demand for liquidity and safety than domestic investors (e.g., domestic banks), which can lead to market segmentation and deviations from the standard term structure of interest rates due to supply-demand imbalances. ${ }^{4}$

\subsection{Single-country studies}

Single-country studies are mostly limited to the case of the United States. Bernanke (2005) has attributed some of the decline in U.S. long-term bond yields since 2000 to a "global savings glut." Starting from the early 2000s, a significant share of global foreign exchange reserves were invested in U.S. Treasury securities (36 percent in 2010), and foreign official holdings of U.S. Treasury securities increased from $\$ 400$ billion in 1994 to $\$ 3$ trillion in 2010, suppressing longterm sovereign bond yields in the U.S. (Beltran and others, 2012).

Motivated by the above arguments, Warnock and Warnock (2009) conduct a quantitative assessment of the change in the FIB, driven by the rising foreign demand on long-term bond yields in the United States, using monthly data spanning January 1984-May 2005. They find that foreign purchases of U.S. Treasury securities have an economically large and statistically significant impact on long-term interest rates. Their simulations suggest that if foreign holdings of U.S. debt had not accumulated over the 12 months ending May 2005, then 10-year Treasury yields would have been around 80 basis points higher. They also consider other financial instruments, including 2-year Treasury yields, high- and low-quality corporate debt (Aaa and Baa), and long-term fixed and shortterm adjustable mortgage rates. The impact of foreign inflows differs across these instruments, but it is always statistically significant and often economically large. In particular, they find that the 2-year bond yields are less affected by foreign flows, explaining this by the fact that they are more closely linked to short-term monetary policy rates rather than macroeconomic fundamentals.

Other studies confirming the negative association between foreign purchases of U.S. Treasuries and long-term rates are Bernanke, Reinhart, and Sack (2004); Beltran and others (2012); and Kaminska, Vayanos, and Zinna (2011). By contrast, Rudebush, Swanson, and Wu (2006) find that changes in the FIB were not so important in explaining the conundrum and the decline in longterm sovereign bond yield volatility observed during the same period.

\footnotetext{
4 For example, Bernanke (2013) argues that the global economic and financial stresses of recent years-triggered by the financial crisis and then by the problems in the euro area - may have elevated the safe-haven demand for Treasury securities, pushing down Treasury yields and implying a lower, or even negative, term premium. Krishnamurthy and Vissing-Jorgensen (2012) estimate that U.S. Treasury bond yields may have been reduced by 73 basis points, on average, from 1926 to 2008 given their extreme safety and liquidity. Hördahl, Tristani, and Vestin (2006) show that safe-haven demand has decreased yields also in the core euro area countries. Kaminska, Vayanos, and Zinna (2011) provide a structural model of the term structure of interest rates that is consistent with no arbitrage, but allows for market segmentation between arbitrageurs and preferredhabitat investors with preferences for specific maturities.
} 


\subsection{Cross-country studies}

Few studies have analyzed the impact of the FIB on long-term sovereign bond yields in a cross-country context. Andritzky (2012) put together a database on the composition of FIB for government securities in the G-20 AEs (six countries) and the euro area (seven countries). Using quarterly data for 2000-2010, he finds that a 10 percentage point increase in the share of debt in AEs held by non-residents leads to a reduction in long-term sovereign bond yields of between 32 and 43 basis points. The impact is stronger at around 60 basis points for the sample of euro area countries.

Hauner and Kumar (2006) explicitly focus on the impact of capital flows in their attempt to resolve the "conundrum" of low government bond yields and high fiscal imbalances observed in G-7 advanced economies before the crisis. Their results suggest that the upward pressures on government bond yields due to chronic weakening of budgetary positions was more than offset by foreign inflows triggered by "safe-haven" considerations. However, they warn about the temporary nature of these effects and predict that upward correction in bond yields is inevitable in the long run.

Unlike the above studies, Lam (2013) finds no significant relationship between the FIB and 5-year forward contracts on 5-year sovereign bond yields in 12 AEs over 1990-2012. However, the dependent variable in his analysis captures only the 5-year maturity and may not fully capture the long-term borrowing costs of the sovereign. In addition, liquidity and default risk characteristics of forward contracts may be different from those of long-term sovereign bond yields, which could affect the estimations. Nevertheless, Lam (2013) finds a significant negative association between forward rates and central bank holdings of sovereign bonds, suggesting that changes in the domestic investor base may have implications for sovereign bond yields. Furthermore, in a similar study for Japan, Ichiue and Shimizu (2012) find that when an increase in government debt is financed entirely by borrowing from external sources, which leads to identical increases in government and foreign debt, the increase in the forward rate is approximately twice that when financed domestically.

As opposed to the previous literature analyzing bond yields, Dell'Erba, Hausmann, and Panizza (2013) focus their attention on the impact of debt composition on bond spreads in 15 AEs. Their analysis suggests that there is no significant association between bond spreads and the share of external debt. However, the coefficient on the debt composition variable turns significant and negative when an interaction term of the debt composition and debt level is added to the regression.

The relationship between the FIB and bond yields was also studied in the context of emerging markets (EMs). Peiris (2010) analyzes the impact of foreign participation on local-currency government bond yields in a panel of 10 emerging markets (EMs) for the period 2000:Q12009:Q1. The estimation results suggest a slightly stronger impact in EMs, with a 10 percentage point increase in the share of foreign debt leading to a 60 basis points decline in domestic bond yields. Using a panel of 13 EMs and 30 AEs between 2000 and 2012, IMF (2013c) and Jaramillo and Zhang (2013) show that "buy and hold" investors, including national and foreign central banks, are able to provide a more stable source of demand for government debt, contributing to the reduction of sovereign bond yields and their volatility. Dell'Erba, Hausmann, and Panizza (2013) analyze the impact of debt composition on bond spreads in 26 EMs. They find that a larger share of foreign debt is associated with higher spreads in EMs. However, this relationship turns insignificant when an interaction term of the debt composition and debt level is added to the regression.

Recognizing the importance of the investor base for sovereign borrowing costs, a separate stream of literature analyzes macroeconomic and institutional determinants of the investor base in a cross-country setting. One of the first studies on the topic is Burger and Warnock (2006), who 
use BIS cross-sectional data on domestic securities in 49 countries (27 EMs and 22 AEs) and find that low inflation, rule of law, and country size positively affect the development of the domestic government bond market, while fiscal balance and GDP growth are negatively correlated with the size of the government bond market. Eichengreen and Luengnaruemitchai (2004) and Claessens, Klingebiel, and Schmukler (2007) extend the BIS data analysis to a panel setting. Consistent with Burger and Warnock (2006), they find that country size, size of the banking system (measured as total deposits/GDP), good institutions, low inflation, and fiscal burden are positively correlated with the size of the domestic bond market. Borensztein and others (2008) distinguish between developments in government, corporate, and financial sector bonds, rather than considering them as one aggregate. They confirm that country size is significantly correlated with the size of bond markets, but this relationship is non-linear and, in the case of government bonds, their point estimates imply that the level off GDP that maximizes the size of the government bond market relative to GDP is US\$6 trillion. They also show that other factors positively affecting domestic bond market activity include trade openness, public debt, institutional quality, lack of capital controls, and privatization of the pension system.

Contrary to the previous studies, Forslund, Lima, and Panizza (2011) find a much weaker association between macroeconomic and institutional factors and the share of domestic government debt in total debt for a wider sample of 95 countries, 33 of which are low income countries. The most puzzling finding is the insignificant impact of inflation history. The authors explain this result by the presence of capital controls, as this relationship turns negative and significant when a subsample of countries with moderate capital controls is considered.

Finally, in addition to studies on the FIB, a number of studies have examined the impact of purchases of government bonds by domestic central banks - including through quantitative easing policies - on long-term interest rates. These studies have focused on the United States, the United Kingdom, and Japan where such purchases have mainly taken place. The literature has focused on event studies and single country regressions. A recent IMF study (IMF 2013a) reviews this literature and finds that the cumulative effects of bond purchase programs were between 90 and 200 basis points in the U.S., between 45 and 160 basis points in the U.K. and between 10 and 30 basis points in Japan.

\section{METHODOLOGY}

We employ panel data methods to analyze the relationship between the FIB and long-term sovereign bond yields in AEs. Our empirical specification includes the standard macroeconomic determinants of long-term sovereign bond yields used in previous studies. We also control for the domestic central bank purchases of government debt. In addition, we introduce the FIB variable as an additional determinant of long-term sovereign bond yields. The empirical specification takes the following form:

$$
y_{i, t}^{10 Y}=\underbrace{\alpha_{i}+\beta_{1} y_{i, t}^{2 Y}+\beta_{2} g_{i, t}+\beta_{3} \pi_{i, t}+\beta_{4} D_{i, t}}_{\text {standard determinants of gov. bond yields }}+\rho C B_{i, t}+\gamma F I B_{i, t}+\lambda_{t}+\varepsilon_{i, t}
$$

where $i$ and $t$ indices denote country and time, respectively, $y^{10 Y}$ and $y^{2 Y}$ are the 10- and 2-year nominal government bond yields, respectively, $g$ is the output growth (y-o-y), $p$ is the CPI inflation (y-o-y), $D$ is the debt-to-GDP ratio, $C B$ is the share of domestic official (central bank) holdings of government debt in total, $F I B$ is the foreign investor base variable, and $e$ is the random error. Estimations are performed using the fixed effects estimator, with $a_{i}$ capturing unobserved country-specific time-invariant determinants of long-term sovereign bond yields (e.g., institutional characteristics, political stability) and $l_{t}$ capturing unobserved time-specific 
common effects influencing all countries simultaneously (e.g., movements of capital between riskier equity and safer fixed income security markets in periods of financial stress).

The first four determinants $\left(y^{2 Y}, g, p\right.$, and $\left.D\right)$ are the standard determinants that were used for assessing the "fair value" of long-term sovereign bond yields in AEs (see Poghosyan, 2012, and references therein):

- Short-term bond yields $\left(y^{2 Y}\right)$ summarize the impact of monetary policy stance on long-term sovereign bond yields. The pass-through from the short-term rate is expected to be positive but less than 1, leaving room for other determinants of long-term sovereign bond yields to have an impact as well.

- Output growth $(g)$ can have a positive or negative impact on long-term sovereign bond yields. On the one hand, an increase in output growth can be driven by a positive shift in potential output growth, which theoretically should have a positive effect on long-term sovereign bond yields as envisaged by the intertemporal utility maximization problem of a representative household (Laubach, 2009; Poghosyan, 2012). On the other hand, the increase may be cyclical and temporary, improving the tax capacity of the country, lowering the sovereign risk, and having a negative effect on bond yields (Cottarelli and Jaramillo, 2012). Which of these opposite effects prevails is an empirical question.

- CPI inflation $(p)$ is expected to have a positive impact on long-term sovereign bond yields. According to the Fisher equation, an increase in expected inflation by one percentage point will lead to a commensurate increase in nominal long-term sovereign bond yields, all else equal, implying that the pass-through effect from expected inflation should be 1 . However, in practice, it is difficult to come up with precise measures of inflation expectations and investors may not be totally rational. This implies that in practice the pass-through effect may be less than 1 (Caporale and Williams, 2002).

- Debt-to-GDP ratio $(D)$ is expected to have a positive impact on long-term sovereign bond yields through two main channels. First, higher government debt crowds out private investments (assuming Ricardian equivalence does not hold) resulting in a lower stock and higher marginal product of capital in the steady state. Second, higher government debt may boost sovereign bond yields through a higher risk premium requested by investors (Engen and Hubbard, 2004).

In addition to standard determinants, we control for the impact of domestic central bank purchases of government debt by introducing a variable that measures the share of domestic official (central bank) holdings of government debt in total. The importance of central bank purchases of government securities on long-term government bond yields was evidenced in a series of recent papers studying the impact of quantitative easing policies launched by the central banks of major AEs in the aftermath of the crisis (Joyce et al., 2011; Krishnamurthy and Vissing-Jorgensen, 2012; and Ueda, 2012).

We augment these standard determinants by an additional variable to assess the impact of the FIB. ${ }^{5}$ We use several FIB measures. First, we use the share of foreign bond holdings in total government debt as an overall measure of the FIB. Motivated by the "conundrum" argument put forward by Alan Greenspan, our prior is that an increase in the share of debt held by foreign investors would lead to a reduction of long-term sovereign bond yields. Second, we use subcomponents of foreign bond holdings to get a more refined view of channels through which the FIB affects long-term sovereign bond yields. For this reason, we use the following three nonoverlapping and exhaustive subcomponents of the share of foreign bond holdings: (i) the share

Changes in the FIB would occur as a result of net purchases of government bonds by non-resident investors (that is total purchases minus total sales and redemptions). As such, these transactions would be recorded as part of gross capital inflows in the balance of payments. It is important to note that this is different from gross capital outflows (i.e. residents buying foreign assets), or net capital inflows (i.e. gross capital inflows minus gross capital outflows). Movements in the exchange rate are likely to be sensitive to both capital inflows and outflows, but for our analysis of sovereign bond yields, we can restrict our attention to only transactions in the domestic bond market between non-resident and resident investors, rather than all portfolio decisions by residents and non-resident investors. 
of official foreign debt in total, (ii) the share of foreign bank debt in total, and (iii) the share of foreign non-bank debt in total.

The impact of foreign official bond holdings on long-term sovereign bond yields is ambiguous. On the one hand, the increase in foreign demand for long-term sovereign bonds will push the yields down. On the other hand, private sector bond holders may require an additional premium following large foreign official bond purchases, in recognition of the fact that official lenders (especially international financial organizations) have a more senior status than private bond holders.

The impact of foreign private bond holdings on long-term sovereign bond yields is expected to be negative. Overall, the negative impact of foreign private bond holdings may more than offset the ambiguous impact of official bond holdings, leading to an overall negative effect of total foreign debt holdings on long-term sovereign bond yields.

We also conduct several robustness checks. First, we use actual data (including smoothed) on macro variables rather than their expectations. Second, we use lagged values of independent variables to alleviate simultaneity issues. Finally, we replace time fixed effects with a crisis dummy and two measures of global uncertainty (VIX and the policy uncertainty index). The impact of the FIB on long-term sovereign bond yields remains qualitatively unchanged in all specifications.

\section{DATA AND DESCRIPTIVE STATISTICS}

Our sample covers 22 AEs that make up 98 percent of the general government debt of all AEs and can, therefore, provide a comprehensive view of the global demand for advanced economy sovereign debt. All data are compiled on a quarterly basis and cover the period from 2004 to 2012. Table 1 describes all variables, their sources, and the country coverage. Descriptive statistics are shown in Table 2.

The dependent variable is the nominal 10-year benchmark bond yield extracted from Bloomberg (daily average), which measures long-term government borrowing costs. The standard drivers of bond yields include the macroeconomic, monetary, and fiscal policy determinants used in previous studies. We capture the impact of monetary policy decisions on long-term bond yields through: (i) 2-year government bond yields (Bloomberg, daily averages), which are closely linked to the monetary policy stance, ${ }^{6}$ and (ii) the share of domestic official holdings of government debt (Arslanalp and Tsuda, 2014), which capture the scale of quantitative easing policies in some AEs where the monetary policy rate hit the zero lower bound. The impact of macroeconomic factors is captured through y-o-y changes in the CPI index (International Financial Statistics) and real output (Haver Analytics), while the impact of fiscal policy is captured by the government debt ratio (Haver Analytics; Arslanalp and Tsuda, 2014).

For the outstanding amount of debt, we use a common definition of government debtconsolidated general government gross debt - to facilitate international comparability. General government debt covers the debt of central, local, and state governments, and social security funds. When it is consolidated, all intra-governmental holdings, such as central government debt held by social security funds, are netted out. All debt figures are expressed in face value and on a gross basis. For European Union (EU) countries, this definition matches the definition of "Maastricht debt," for which data are readily available from Eurostat's Quarterly Government Finance Statistics. ${ }^{7}$ For others, they are constructed by Arslanalp and Tsuda (2014) from national flow of funds data using the same definition of government debt. The debt-to-GDP ratio is

We use the 2-year rates as an indicator of not just current, but also expected, policy rates in the near term.

Switzerland also provides government debt figures consistent with the definition of Maastricht debt. The data for Switzerland are on an annual basis, so quarterly figures are interpolated. 
calculated as the stock of debt in the referenced quarter divided by the 4-quarter moving sum of GDP. Quarterly GDP data are available from Eurostat for EU countries and Haver Analytics for other advanced economies.

Table 1

Description of Variables and Their Sources

\begin{tabular}{|c|c|c|c|}
\hline Variable & Description & $\begin{array}{l}\text { Expected } \\
\text { sign }\end{array}$ & Source \\
\hline \multicolumn{4}{|l|}{ Dependent variable } \\
\hline $\begin{array}{l}\text { Nominal long-term interest } \\
\text { rate }\end{array}$ & $\begin{array}{l}\text { Nominal } 10 \text { year benchmark bond yield } \\
\text { (daily average) }\end{array}$ & & Bloomberg* \\
\hline \multicolumn{4}{|l|}{ Standard determinants } \\
\hline $\begin{array}{l}\text { Nominal short-term interest } \\
\text { rate }\end{array}$ & Nominal 2 year bond yield (daily average) & $(+)$ & Bloomberg \\
\hline $\begin{array}{l}\text { Real GDP growth (actual and } \\
\text { expected) }\end{array}$ & $\begin{array}{l}\text { Percentage change in y-o-y quarterly real } \\
\text { output }\end{array}$ & $(?)$ & $\begin{array}{l}\text { Haver Analytics, } \\
\text { Consensus Forecast }\end{array}$ \\
\hline $\begin{array}{l}\text { CPI inflation (actual and } \\
\text { expected) }\end{array}$ & $\begin{array}{l}\text { Percentage change in y-o-y quarterly CPI } \\
\text { index (end of period) }\end{array}$ & $(+)$ & IFS, Consensus Forecast \\
\hline $\begin{array}{l}\text { Debt ratio (actual and } \\
\text { expected) }\end{array}$ & $\begin{array}{l}\text { Ratio of general government debt to four- } \\
\text { quarter moving sum of GDP (in percent) }\end{array}$ & $(+)$ & $\begin{array}{l}\text { Arslanalp and Tsuda } \\
\text { (2012), Haver Analytics, } \\
\text { IFS }\end{array}$ \\
\hline Domestic official debt share & $\begin{array}{l}\text { Ratio of domestic official debt to total } \\
\text { government debt }\end{array}$ & $(-)$ & $\begin{array}{l}\text { Arslanalp and Tsuda } \\
\text { (2012) }\end{array}$ \\
\hline \multicolumn{4}{|l|}{ Foreign investor base } \\
\hline Foreign debt share & $\begin{array}{l}\text { Ratio of foreign debt to total government } \\
\text { debt }\end{array}$ & $(-)$ & $\begin{array}{l}\text { Arslanalp and Tsuda } \\
\text { (2012) }\end{array}$ \\
\hline Foreign official debt share & $\begin{array}{l}\text { Ratio of foreign official debt to total } \\
\text { government debt }\end{array}$ & $(+)$ & $\begin{array}{l}\text { Arslanalp and Tsuda } \\
\text { (2012) }\end{array}$ \\
\hline Foreign bank debt share & $\begin{array}{l}\text { Ratio of foreign bank debt to total } \\
\text { government debt }\end{array}$ & $(-)$ & $\begin{array}{l}\text { Arslanalp and Tsuda } \\
\text { (2012) }\end{array}$ \\
\hline Foreign non-bank debt share & $\begin{array}{l}\text { Ratio of foreign non-bank debt to total } \\
\text { government debt }\end{array}$ & $(-)$ & $\begin{array}{l}\text { Arslanalp and Tsuda } \\
\text { (2012) }\end{array}$ \\
\hline
\end{tabular}

Note: The sample covers the following advanced economies: Australia, Austria, Belgium, Canada, Czech Republic, Denmark, Finland, France, Germany, Greece, Ireland, Italy, Japan, Korea, the Netherlands, New Zealand, Portugal, Spain, Sweden, Switzerland, the United Kingdom, and the United States.

* Data for Ireland comes from ECB's harmonized long-term interest rates warehouse.

For the foreign investor base of debt, we use the dataset constructed for advanced economies by Arslanalp and Tsuda (2014). This dataset has several advantages for the purpose of our analysis and provides a major improvement relative to the datasets used in previous cross-country studies. First, it is based on a common definition of government debt, as explained above (general government gross debt on a consolidated basis). Second, a common estimation methodology is used based on harmonized international data sources, such as the BIS International Banking Statistics (IBS), IMF International Financial Statistics (IFS), and IMF/World Bank Quarterly External Debt Statistics (QEDS). This ensures that all data are based on the same residency principle of the investor, include comparable definitions of general government, and use similar definitions of debt instruments. Third, all data are compiled either in face value or adjusted for valuation changes, where appropriate, to track investor transactions as well as holdings. This is important to eliminate any spurious correlation between long-term sovereign bond yields and 
investor holdings. Finally, foreign investor holdings are estimated separately for the foreign official sector, foreign banks, and foreign nonbanks, in contrast to national data sources that usually classify them under one category ("rest of the world"). A more detailed description of the dataset, including stylized facts about recent trends (composition of foreign holdings, differences across countries, etc.) is provided in Arslanalp and Tsuda (2014).

Table 2

Descriptive Statistics

\begin{tabular}{lccccc}
\hline \multicolumn{1}{c}{ Variable } & Obs & Mean & Std. Dev. & Min & Max \\
\hline Nominal long-term interest rate & 792 & 4.1 & 2.4 & 0.5 & 30.9 \\
Nominal short-term interest rate & 792 & 4.1 & 14.1 & 0.2 & 191.9 \\
Real GDP growth & 792 & 1.5 & 3.0 & -10.1 & 8.7 \\
CPI inflation & 792 & 2.1 & 1.4 & -6.1 & 7.4 \\
Debt ratio & 792 & 65.1 & 39.2 & 15.4 & 223.0 \\
Doestic official debt share & 792 & 3.5 & 4.4 & 0.0 & 27.6 \\
Foreign debt share & 792 & 41.1 & 21.1 & 3.2 & 83.3 \\
Foreign official debt share & 792 & 13.5 & 11.5 & 1.3 & 76.1 \\
Foreign bank debt share & 792 & 10.4 & 7.2 & 0.3 & 39.6 \\
Foreign non-bank debt share & 792 & 17.2 & 13.3 & 0.0 & 56.2 \\
Foreign non-official (bank and non-bank) debt share & 792 & 27.6 & 18.5 & 0.8 & 70.8 \\
\hline \hline
\end{tabular}

We use a number of variables for the robustness test of our main results. To capture the forward looking nature of markets we use projections of inflation and real GDP growth from Consensus Forecasts. ${ }^{8}$ The projected ratios are compiled from different vintages of the IMF World Economic Outlook (WEO) database. For each vintage, we calculate the maximum debt-to-GDP ratio over the 5-year projection horizon, as a way to capture market concerns about the debt trajectory. The WEO database is updated semi-annually, so quarterly figures are interpolated. The interpolation assumes that debt-to-GDP projections change steadily over a six-month period for most of the countries in the sample.

Finally, the descriptive statistics suggest that data is quite heterogeneous in some cases, such as real growth rates. This can lead to misspecification of the fixed-effects model. Hence, we checked the estimates on a winsorized sample as well. The results remained qualitatively unchanged and are available from the authors upon request.

To illustrate our main hypothesis, we present the relationship between long-term government bond yields and the FIB in selected AEs (Figure 1). As shown in the figure, bond yields and the FIB move in the opposite direction, and this divergence became particularly pronounced following the crisis. The share of the FIB has been growing in "safe haven" recipient AEs, such as the United States, the United Kingdom, Germany, and to a lesser extent Japan, and this increase has coincided with a decline in bond yields in these countries. By contrast, the share of the FIB has dipped in periphery euro area countries, such as Spain and Italy, and this decline has coincided with a rapid increase in bond yields in these countries. It is also interesting to observe the high persistency of the FIB variable, suggesting that foreign investors adjust their holdings of sovereign securities gradually. ${ }^{9}$

\footnotetext{
8 Consensus Forecast provides projections for the current year and the following year. To construct a one-year ahead projection for each quarter, we took the weighted average of these two projections, where the weights were determined as follows: $3 / 4$ and $1 / 4$, respectively, for the first quarter; $1 / 2$ and $1 / 2$ for the second quarter, and so forth.

9 The autocorrelation coefficient of the foreign investor base variable is 0.995 for the first lag and gradually declines to 0.915 for the tenth lag.
} 
Figure 1

Sovereign bond yields and foreign investor base in selected advanced economies

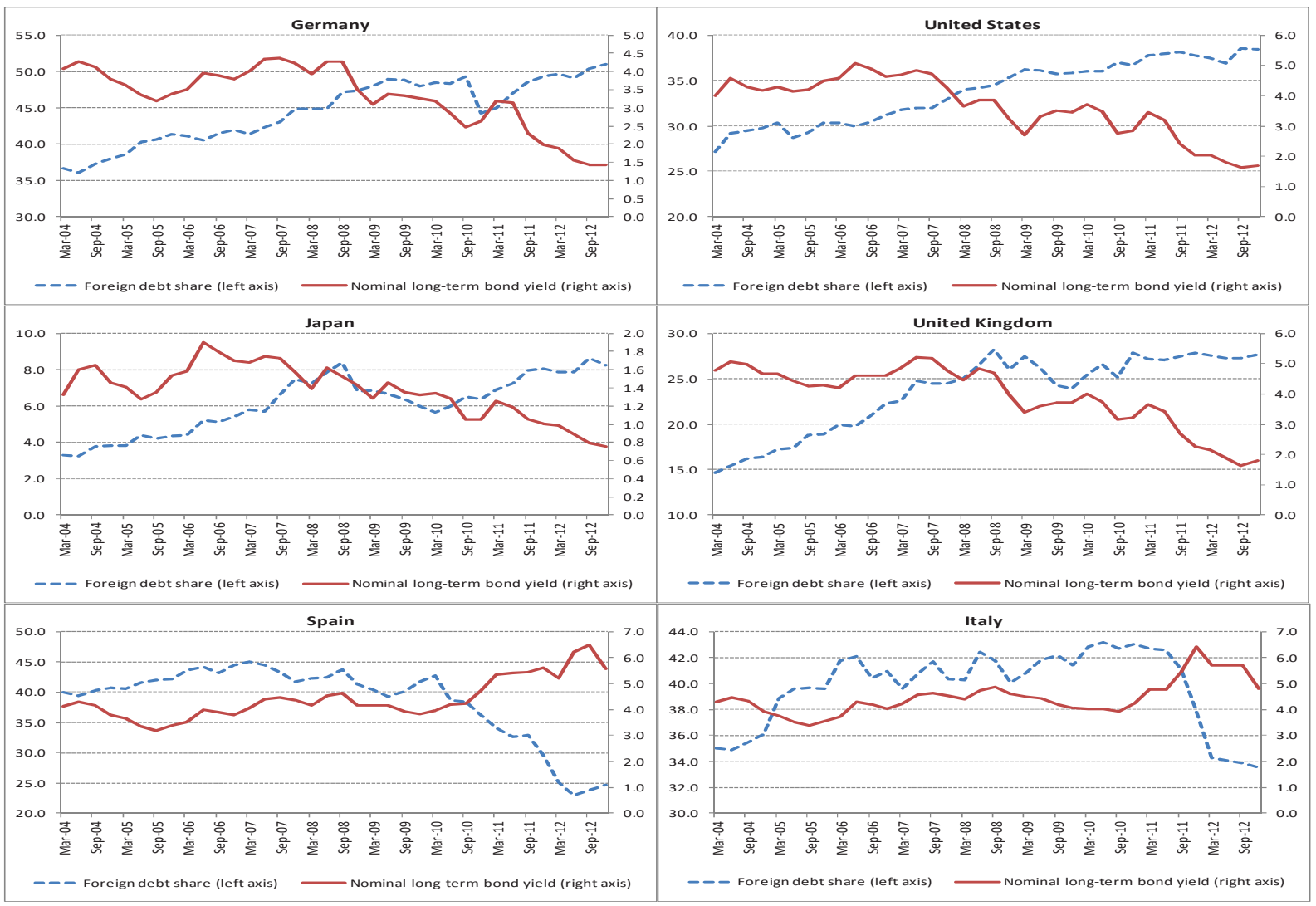

Note: The figure shows 10-year government bond yields and the share of government bond market held by foreigners.

Another way to illustrate the relationship between the FIB and sovereign bond yields is to juxtapose the within variation of the two variables in a scatter plot (Figure 2). The within transformation measures the difference between each data point of a variable from its countryspecific mean and eliminates country-specific unobserved heterogeneity (fixed effects). ${ }^{10}$ As shown in the figure, the within transformations of sovereign bond yields and the FIB are inversely related and this relationship is not driven by a few outliers. The inverse association suggests that an increase in a country's FIB over time was on average associated with a reduction in sovereign bond yields. Of course, the dynamics of bond yields also reflect the impact of other fundamental determinants (e.g., monetary policy rate, output growth, inflation) as well as central bank purchases of government debt, which we will take into account in our empirical analysis to separate the impact of the FIB from other factors.

10 More formally, the within transformation of variable $X_{i t}$ can be written as $\left(X_{i t}-X_{i}\right)$, where $X_{i .}$ is the average for country $i$. In Figure 2, we have also added sample means $(X)$ of the FIB and sovereign bond yields to their respective within transformations in order to move the scatter plot away from the axis origin. 
Figure 2

Sovereign bond yields and foreign investor base (within variation)

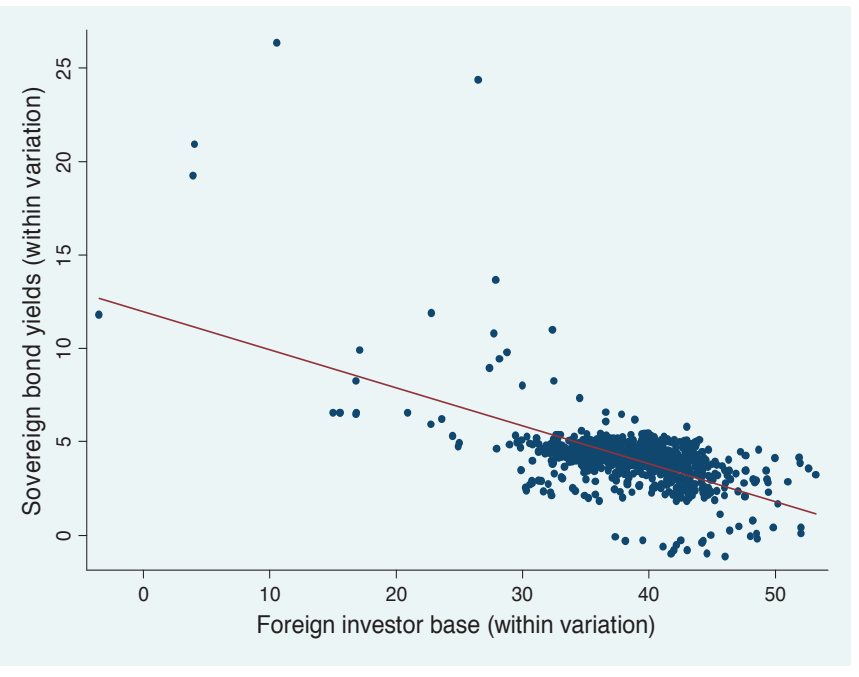

\section{ESTIMATION RESULTS}

In this section, we discuss the results from the baseline specification. Then we present robustness checks. Finally, we assess the impact of changes in the FIB on sovereign bond yields in the aftermath of the crisis.

\subsection{Baseline specification}

Table 3 reports estimation results from the baseline specification. ${ }^{11}$ Column 1 shows results from the specification with the foreign share of total government debt securities issued as a measure of the FIB. Column 2 shows results from the specification with the two subcomponents of the foreign debt share: official and non-official, respectively.

The standard determinants of sovereign bond yields have the right sign and are significant in both specifications. A 100 basis points increase in the nominal short-term bond yield leads to an increase of 8 basis points in long-term sovereign bond yields. This result is comparable to estimates found in studies on AEs that do not (e.g., Poghosyan, 2012) and do (e.g., Andritzky, 2012) consider the impact of the FIB. Given that the short-term sovereign bond yields are closely related to the monetary policy rate, this result suggests that monetary policy has a less than oneto-one pass-through effect on long-term sovereign bond yields, with the rest of the impact linked to changes in macroeconomic and fiscal factors.

In terms of macroeconomic determinants, bond yields are negatively affected by the expected real output growth rate and positively by the expected inflation rate. A 1 percent increase in the expected real growth rate leads to a 48-49 basis points decline in bond yields, while a 1 percent increase in expected inflation leads to an increase of 18-23 basis points in bond yields. The negative impact of growth is consistent with the findings of Baldacci and Kumar (2010) and can be explained by the stronger influence of cyclical (relative to structural) factors on growth in the relatively high frequency (quarterly) data used in the analysis. The smaller impact of inflation could be driven by the fact that, in AEs, inflation expectations have been firmly anchored at a low level, diminishing their importance for long-term investors.

11 We have checked variables for stationarity. Although individual/country-specific ADF tests suggest that some variables are I(1), co-integration tests using Johansen procedure confirm co-integration for those variables. 
Table 3

Baseline Specification: Total Sample

\begin{tabular}{|c|c|c|}
\hline & 1 & 2 \\
\hline \multirow[t]{2}{*}{ Short-term bond yield (2 year) } & $0.0790^{* * *}$ & $0.0772^{* * *}$ \\
\hline & $(25.666)$ & $(24.212)$ \\
\hline \multirow[t]{2}{*}{ Real GDP growth (y-o-y) [Consensus Forecast] } & $-0.4960^{* * *}$ & $-0.4807^{* * *}$ \\
\hline & $(-10.481)$ & $(-10.058)$ \\
\hline \multirow[t]{2}{*}{ CPI inflation (y-o-y) [Consensus Forecast] } & $0.2318^{* * *}$ & $0.1819^{* *}$ \\
\hline & $(2.603)$ & $(1.977)$ \\
\hline \multirow[t]{2}{*}{ Debt/GDP*100 [WEO projection, 5 year max] } & $0.0268^{* * *}$ & $0.0282^{* * *}$ \\
\hline & $(8.120)$ & $(8.392)$ \\
\hline \multirow[t]{2}{*}{ Domestic official debt share } & $-0.0537^{* * *}$ & $-0.0522^{* * *}$ \\
\hline & $(-3.656)$ & $(-3.553)$ \\
\hline \multirow[t]{2}{*}{ Foreign debt share } & $-0.0811^{* * *}$ & \\
\hline & $(-10.625)$ & \\
\hline \multirow[t]{2}{*}{ Foreign official debt share } & & $-0.0691^{* * *}$ \\
\hline & & $(-7.243)$ \\
\hline \multirow[t]{2}{*}{ Foreign non-official (bank and non-bank) debt share } & & $-0.0851^{* * *}$ \\
\hline & & $(-10.837)$ \\
\hline \multirow[t]{2}{*}{ Constant } & $6.3002^{* * *}$ & $6.3030^{* * *}$ \\
\hline & $(13.931)$ & $(13.969)$ \\
\hline Observations & 792 & 792 \\
\hline R-squared & 0.804 & 0.805 \\
\hline Number of countries & 22 & 22 \\
\hline R-square adjusted & 0.788 & 0.789 \\
\hline R-square overall & 0.184 & 0.167 \\
\hline
\end{tabular}

Note: The dependent variable is the nominal long-term bond yield (10 year). Estimations are performed using the fixed effects estimator controlling for time effects (not reported).

Robust t-statistics are in parentheses. ${ }^{* *}, * *$, and $*$ denote significance at 1,5 , and 10 percent level, respectively.

As for fiscal determinants, government debt has a positive and significant impact on bond yields. A 1 percentage point increase in the expected debt-to-GDP ratio leads to an increase of 3 basis points in bond yields. This result is comparable to the 2-7 basis points range found in studies that do not consider the impact of the FIB (see Poghosyan, 2012, and references therein). Domestic official debt purchases also have a significant impact on bond yields. A 1 percentage point increase in the share of debt held by the central banks contributes to a reduction of 5 basis points in bond yields. This suggests that central bank purchases of government bonds may have reduced bond yields by about 15 basis points in Japan, 120 basis points in the United Kingdom, and 30 basis points in the United States. With the exception of the United States, these are within the range of estimates found in other studies, including event studies. ${ }^{12}$

Finally, the FIB variable has a significant impact on bond yields in most specifications. This emphasizes the importance of the FIB as an additional determinant of bond yields in AEs. As expected, the coefficient has a negative sign: a 1 percentage point higher share of foreign debt in total leads to a decline in bond yields of 8 basis points. This result supports the "conundrum" effect, according to which a substantial increase in foreign demand for AE securities led to a compression of their long-term bond yields in the mid-2000s.

12 The U.S. may be an exception in the results because it also benefits from significant foreign central bank purchases of its government bonds, which may have amplified the downward pressure on U.S. Treasury bond yields. 
However, the impact of the foreign debt share slightly differs across its subcomponents. A 1 percentage point rise in the foreign official share in total debt leads to a 7 basis points decrease in bond yields, while a 1 percentage point increase in the foreign private share in total debt leads to a decline in bond yields of 8.5 basis points. This supports the view that capital flows from foreign official investors are relatively more stable, with a long-term horizon and less commercial orientation, making them less sensitive to changes in market sentiment. However, these results should be interpreted with caution since the difference between the coefficients of FIB subcomponents is not statistically significant.

We have also estimated the baseline model for 11 euro area countries in the sample (Table 4). The main difference between these countries and the other AEs is that they share a single currency. As a result, risks stemming from fiscal variables are likely to be more pronounced in these countries compared to the rest of the sample. Indeed, the sensitivity of bond yields to the debt ratio is slightly higher in euro area countries ( 5 basis points). In addition, the impact of the domestic official investor base is stronger in these countries (19 basis points), which is consistent with the fact that ECB interventions in the aftermath of the crisis had a strong impact on sovereign bond yields in the euro area. However, the impact of the FIB is comparable to that of the total sample, providing evidence in support of the "conundrum" effect in euro area countries. ${ }^{13}$

Table 4

Baseline Specification: Euro Area Countries

\begin{tabular}{|c|c|c|}
\hline & 1 & 2 \\
\hline \multirow[t]{2}{*}{ Short-term bond yield (2 year) } & $0.0737^{* * *}$ & $0.0732^{* * *}$ \\
\hline & $(17.884)$ & $(16.859)$ \\
\hline \multirow[t]{2}{*}{ Real GDP growth (y-o-y) [Consensus Forecast] } & $-0.5061^{* * *}$ & $-0.4938^{* * *}$ \\
\hline & $(-5.649)$ & $(-5.242)$ \\
\hline \multirow[t]{2}{*}{ CPI inflation (y-o-y) [Consensus Forecast] } & $0.5662^{* * *}$ & $0.5269^{* *}$ \\
\hline & $(2.868)$ & $(2.419)$ \\
\hline \multirow[t]{2}{*}{ Debt/GDP*100 [WEO projection, 5 year max] } & $0.0506^{* * *}$ & $0.0511^{* * *}$ \\
\hline & $(5.853)$ & $(5.844)$ \\
\hline \multirow[t]{2}{*}{ Domestic official debt share } & $-0.1895^{*}$ & $-0.1946^{*}$ \\
\hline & $(-1.829)$ & $(-1.864)$ \\
\hline \multirow[t]{2}{*}{ Foreign debt share } & $-0.0741^{* * *}$ & \\
\hline & $(-5.329)$ & \\
\hline \multirow[t]{2}{*}{ Foreign official debt share } & & $-0.0696^{* * *}$ \\
\hline & & $(-3.997)$ \\
\hline \multirow[t]{2}{*}{ Foreign non-official (bank and non-bank) debt share } & & $-0.0748^{* * *}$ \\
\hline & & $(-5.339)$ \\
\hline \multirow[t]{2}{*}{ Constant } & $4.6796^{* * *}$ & $4.6938^{* * *}$ \\
\hline & $(3.562)$ & $(3.567)$ \\
\hline Observations & 396 & 396 \\
\hline R-squared & 0.849 & 0.850 \\
\hline Number of countries & 11 & 11 \\
\hline R-square adjusted & 0.827 & 0.827 \\
\hline R-square overall & 0.681 & 0.681 \\
\hline
\end{tabular}

Note: The dependent variable is the nominal long-term bond yield (10 year). Estimations are performed using the fixed effects estimator controlling for time effects (not reported).

Robust t-statistics are in parentheses. $* * *, *$, and $*$ denote significance at 1,5 , and 10 percent level, respectively.

\footnotetext{
13 Moreover, several studies, such as Acharya and Steffen (2013), find that increasing "home bias"_-greater exposure of domestic banks to sovereign bonds - after the European banking crisis may have played a role in pushing down bond yields in periphery countries. All else equal, that would suggest that the impact of foreign outflows from euro area periphery countries on bond yields may have been even higher than suggested in Table 4
} 


\subsection{Robustness Checks}

We conduct several robustness checks to assess the sensitivity of our key findings to various assumptions. First, we replace expectations of macro and fiscal variables with actual data (Table 5). The magnitude of coefficients on macro and fiscal variables has been affected by this replacement, providing support to the argument advanced in Engen and Hubbard (2004) and Laubach (2009). According to this argument, in the presence of forward-looking market participants, sovereign borrowing costs depend on expected rather than actual macro and fiscal determinants and using expectations of determinants helps to disentangle the effect of fiscal policy from other factors influenced by the business cycle. Nevertheless, the impact of the FIB is not affected when using actual data, suggesting that our results on the importance of the FIB are not sensitive to this assumption.

Table 5

Robustness Check: Using Actual Data, Instead of Expectations

\begin{tabular}{|c|c|c|}
\hline & 1 & 2 \\
\hline \multirow[t]{2}{*}{ Short-term bond yield (2 year) } & $0.0886^{* * *}$ & $0.0852^{* * *}$ \\
\hline & $(15.997)$ & $(11.967)$ \\
\hline \multirow[t]{2}{*}{ Real GDP growth (y-o-y) } & $-0.1663^{* *}$ & $-0.1617^{* *}$ \\
\hline & $(-2.186)$ & $(-2.272)$ \\
\hline \multirow[t]{2}{*}{ CPI inflation (y-o-y) } & 0.0828 & 0.0291 \\
\hline & $(1.561)$ & $(0.613)$ \\
\hline \multirow[t]{2}{*}{ Debt/GDP*100 } & $0.0552^{* * *}$ & $0.0591^{* * *}$ \\
\hline & $(4.108)$ & $(3.914)$ \\
\hline \multirow[t]{2}{*}{ Domestic official debt share } & $-0.0685^{*}$ & $-0.0668^{* *}$ \\
\hline & $(-1.899)$ & $(-2.092)$ \\
\hline \multirow[t]{2}{*}{ Foreign debt share } & $-0.0771^{* * *}$ & \\
\hline & $(-4.050)$ & \\
\hline \multirow[t]{2}{*}{ Foreign official debt share } & & $-0.0548^{* *}$ \\
\hline & & $(-2.282)$ \\
\hline \multirow[t]{2}{*}{ Foreign non-official (bank and non-bank) debt share } & & $-0.0849^{* * *}$ \\
\hline & & $(-4.326)$ \\
\hline \multirow[t]{2}{*}{ Constant } & $4.0049^{* * *}$ & $3.9255^{* * *}$ \\
\hline & $(3.770)$ & $(3.480)$ \\
\hline Observations & 792 & 792 \\
\hline R-squared & 0.816 & 0.820 \\
\hline Number of countries & 22 & 22 \\
\hline R-square adjusted & 0.806 & 0.810 \\
\hline R-square overall & 0.135 & 0.114 \\
\hline
\end{tabular}

Note: The dependent variable is the nominal long-term bond yield (10 year). Estimations are performed using the fixed effects estimator controlling for time effects (not reported).

Robust t-statistics are in parentheses. $* * *, * *$, and $*$ denote significance at 1,5 , and 10 percent level, respectively.

Second, we follow the approach by Correia-Nunes and Stemitsiotis (1995) and use smoothed values of actual macro and fiscal variables, instead of market analyst expectations and WEO projections (Table 6). ${ }^{14}$ Using this approach leads to slightly different coefficient estimates compared to the baseline, but the impact of the FIB and its components remains unchanged.

14 The smoothing is performed using MA $(4,1,4)$ representation: $1 / 9 *\left(x_{t-4}+x_{t-3}+x_{t-2}+x_{t-1}+x_{t}+x_{t+1}+x_{t+2}+x_{t+3}+x_{t+4}\right)$, where $x_{t}$ is the macro and fiscal variable of interest (real GDP growth, inflation, and debt-to-GDP ratio). 
Table 6

Robustness Check: Using Smoothed Values of Macro Variables, Instead of Expectations

\begin{tabular}{|c|c|c|}
\hline & 1 & 2 \\
\hline \multirow[t]{2}{*}{ Short-term bond yield ( 2 year) } & $0.0827^{* * *}$ & $0.0802^{* * *}$ \\
\hline & $(12.630)$ & $(10.026)$ \\
\hline \multirow[t]{2}{*}{ Real GDP growth (y-o-y) [smoothed] } & $-0.3418^{* *}$ & $-0.3319^{* *}$ \\
\hline & $(-2.457)$ & $(-2.474)$ \\
\hline \multirow[t]{2}{*}{ CPI inflation (y-o-y) [smoothed] } & 0.2066 & 0.1416 \\
\hline & $(1.634)$ & $(1.083)$ \\
\hline \multirow[t]{2}{*}{ Debt/GDP*100 [smoothed $]$} & $0.0551^{* * *}$ & $0.0577^{* * *}$ \\
\hline & $(4.382)$ & $(4.102)$ \\
\hline \multirow[t]{2}{*}{ Domestic official debt share } & $-0.0762^{* *}$ & $-0.0734^{* *}$ \\
\hline & $(-2.164)$ & $(-2.338)$ \\
\hline \multirow[t]{2}{*}{ Foreign debt share } & $-0.0688 * * *$ & \\
\hline & $(-3.492)$ & \\
\hline \multirow[t]{2}{*}{ Foreign official debt share } & & $-0.0540^{* *}$ \\
\hline & & $(-2.190)$ \\
\hline \multirow[t]{2}{*}{ Foreign non-official (bank and non-bank) debt share } & & $-0.0750^{* * *}$ \\
\hline & & $(-3.482)$ \\
\hline \multirow[t]{2}{*}{ Constant } & $4.0042^{* * *}$ & $4.0304^{* * *}$ \\
\hline & $(3.652)$ & $(3.569)$ \\
\hline Observations & 792 & 792 \\
\hline R-squared & 0.825 & 0.826 \\
\hline Number of countries & 22 & 22 \\
\hline R-square adjusted & 0.815 & 0.817 \\
\hline R-square overall & 0.161 & 0.141 \\
\hline
\end{tabular}

Note: The dependent variable is the nominal long-term bond yield (10 year). Estimations are performed using the fixed effects estimator controlling for time effects (not reported).

Robust t-statistics are in parentheses. $* * * * *$, and $*$ denote significance at 1,5 , and 10 percent level, respectively.

Third, we use lagged dependent variables for standard determinants of bond yields (Table 7). The main motivation is to alleviate the possible simultaneity between sovereign borrowing costs and the macroeconomic environment. Lagging standard determinants of bond yields slightly altered their magnitude and significance compared to the baseline. However, the sign and the significance of the FIB variables have remained unchanged. The sensitivity of sovereign bond yields to the foreign debt share is slightly higher in this specification (10 basis points), which is mostly due to the larger impact of the non-official foreign debt (11 basis points).

Fourth, we assess the sensitivity of the results to the inclusion of the crisis dummy and observable global factors, instead of time-fixed effects capturing unobserved heterogeneity. The crisis dummy or global risk aversion indicators could capture the impact of changing preferences or risk-appetite of foreign (and domestic) investors during the crisis period. Table 8 shows estimation results using the VIX index as a measure of global risk aversion. The impact of the FIB and standard determinants remain unchanged in this specification. As expected, bond yields tend to increase with rising global risk aversion ( 2 basis points per unit increase in the VIX). In addition, sovereign bond yields in all AEs have declined by $117-125$ basis points in the aftermath of the crisis. ${ }^{15}$ This decline could be driven by the shift of capital from riskier equity to safer fixed income securities markets following the crisis. Table 9 shows estimation results using the

15 The results are robust to the inclusion of the crisis dummy and VIX variables one at a time. We also included an interaction term between the crisis dummy and domestic official debt share variable to address the issue that central bank bond purchases may have been more powerful during the crisis. The results for the FIB remain robust to these changes in the model specification. 
news-based economic policy uncertainty index by Bloom (2009) and Baker, Bloom, and Davis (2013). ${ }^{16}$ Once again, the impact of the FIB and standard determinants remains unaffected. The crisis dummy coefficient is slightly lower (54-59 basis points), while the policy uncertainty index is negative and significant. The latter suggests that policy uncertainty triggers capital outflows from riskier equity to safer fixed income markets.

Table 7

Robustness Check: Using Lagged Independent Variables

\begin{tabular}{|c|c|c|}
\hline & 1 & 2 \\
\hline Short-term bond yield (2 year) [lagged] & $\begin{array}{c}0.0640^{* * *} \\
(4.654)\end{array}$ & $\begin{array}{c}0.0584^{* * *} \\
(3.657)\end{array}$ \\
\hline Real GDP growth (y-o-y) [Consensus Forecast, lagged] & $\begin{array}{c}-0.5308^{* * *} \\
(-2.923)\end{array}$ & $\begin{array}{c}-0.4978^{* * *} \\
(-3.647)\end{array}$ \\
\hline CPI inflation (y-o-y) [Consensus Forecast, lagged] & $\begin{array}{l}0.0259 \\
(0.175)\end{array}$ & $\begin{array}{l}-0.1123 \\
(-0.535)\end{array}$ \\
\hline Debt/GDP*100 [WEO projection, 5 year max, lagged] & $\begin{array}{c}0.0270^{* *} \\
(2.364)\end{array}$ & $\begin{array}{l}0.0316^{* *} \\
(2.432)\end{array}$ \\
\hline Domestic official debt share [lagged] & $\begin{array}{l}-0.0577^{*} \\
(-1.820)\end{array}$ & $\begin{array}{l}-0.0526^{*} \\
(-1.854)\end{array}$ \\
\hline Foreign debt share & $\begin{array}{c}-0.1043^{* * *} \\
(-5.447)\end{array}$ & \\
\hline Foreign official debt share & & $\begin{array}{c}-0.0666^{* *} \\
(-2.610)\end{array}$ \\
\hline Foreign non-official (bank and non-bank) debt share & & $\begin{array}{c}-0.1148^{* * *} \\
(-4.978)\end{array}$ \\
\hline Constant & $\begin{array}{c}7.8774^{* * *} \\
(7.791)\end{array}$ & $\begin{array}{c}7.8068^{* * *} \\
(7.708) \\
\end{array}$ \\
\hline Observations & 770 & 770 \\
\hline R-squared & 0.713 & 0.723 \\
\hline Number of countries & 22 & 22 \\
\hline R-square adjusted & 0.697 & 0.708 \\
\hline R-square overall & 0.0696 & 0.0473 \\
\hline
\end{tabular}

Note: The dependent variable is the nominal long-term bond yield (10 year). Estimations are performed using the fixed effects estimator controlling for time effects (not reported).

Robust t-statistics are in parentheses. $* * * * *$, and $*$ denote significance at 1,5 , and 10 percent level, respectively.

Fifth, we examine whether the FIB may be driven by the same macro variables driving bond yields. For this, we look for potential signs of multicollinearity among independent variables. The correlation matrix for independent variables shows that bilateral correlations are not very high, including between the FIB and macro variables (Table 10). The highest correlation (0.86) is between the foreign share and the foreign non-official share of government debt, but we include these variables separately in the regressions. Small correlation coefficients do not support the hypothesis that the FIB may be driven by the same macro variables driving bond yields, rather than having its own impact on bond yields.

16 The index of economic policy uncertainty refers to uncertainty surrounding economic policies in the United States and euro area and is a weighted average of three indicators: the frequency with which terms like "economic policy" and "uncertainty" appear together in the media; the number of tax provisions that will expire in coming years; and the dispersion of forecasts of future government outlays and inflation. 
Table 8

Robustness Check: Replacing TE with VIX and Crisis Dummy

\begin{tabular}{|c|c|c|}
\hline & 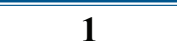 & 2 \\
\hline \multirow[t]{2}{*}{ Short-term bond yield ( 2 year) } & $0.0852^{* * *}$ & $0.0835^{* * *}$ \\
\hline & $(9.305)$ & $(7.693)$ \\
\hline \multirow[t]{2}{*}{ Real GDP growth (y-o-y) [Consensus Forecast] } & $-0.2838^{* *}$ & $-0.2770^{* *}$ \\
\hline & $(-2.166)$ & $(-2.291)$ \\
\hline \multirow[t]{2}{*}{ CPI inflation (y-o-y) [Consensus Forecast] } & $0.4013^{*}$ & $0.3596^{* *}$ \\
\hline & $(1.995)$ & $(2.284)$ \\
\hline \multirow[t]{2}{*}{ Debt/GDP*100 [WEO projection, 5 year max] } & $0.0294^{* *}$ & $0.0298^{* *}$ \\
\hline & $(2.383)$ & $(2.367)$ \\
\hline \multirow[t]{2}{*}{ Domestic official debt share } & $-0.0786^{*}$ & $-0.0767^{* *}$ \\
\hline & $(-2.018)$ & $(-2.121)$ \\
\hline \multirow[t]{2}{*}{ Foreign debt share } & $-0.0682^{* * *}$ & \\
\hline & $(-4.041)$ & \\
\hline \multirow[t]{2}{*}{ Foreign official debt share } & & $-0.0587^{* *}$ \\
\hline & & $(-2.611)$ \\
\hline \multirow[t]{2}{*}{ Foreign non-official (bank and non-bank) debt share } & & $-0.0724^{* * *}$ \\
\hline & & $(-4.049)$ \\
\hline \multirow[t]{2}{*}{ Crisis dummy (=1 for $2008 \mathrm{Q} 3$ onwards) } & $-1.1738^{* * *}$ & $-1.2488^{* * *}$ \\
\hline & $(-3.732)$ & $(-3.333)$ \\
\hline \multirow[t]{2}{*}{ VIX } & $0.0201^{* * *}$ & $0.0207^{* * *}$ \\
\hline & $(3.120)$ & $(3.213)$ \\
\hline \multirow[t]{2}{*}{ Constant } & $4.4929^{* * *}$ & $4.5502^{* * *}$ \\
\hline & $(3.803)$ & $(3.946)$ \\
\hline Observations & 792 & 792 \\
\hline R-squared & 0.721 & 0.722 \\
\hline Number of countries & 22 & 22 \\
\hline R-square adjusted & 0.719 & 0.719 \\
\hline R-square overall & 0.200 & 0.185 \\
\hline
\end{tabular}

Note: The dependent variable is the nominal long-term bond yield (10 year). Estimations are performed using the fixed effects estimator. Robust $t$-statistics are in parentheses. $* * *, * *$, and $*$ denote significance at 1,5 , and 10 percent level, respectively.

Finally, we run country-specific Granger causality tests to see which way the causality between the FIB and bond yields is likely to run. The tests suggest that for the vast majority of countries, the causality runs from the FIB to bond yields, and not vice versa (Table 11). Exceptions are Greece, Ireland, Italy, and Portugal, i.e. only some of the euro area periphery countries (or 4 countries out of 22 in the sample). ${ }^{17}$ For these countries, Granger causality tests suggest that the FIB may have reacted to rising bond yields (e.g., presumably, foreign investors cut exposure to these countries after taking large losses due to sharp rises in bond yields).

17 This causality test is rejected consistently for these countries using lag periods up to 3 quarters. The test is rejected for Spain ( 3 lags), Switzerland (3 lags), and Sweden (1 and 2 lags) in only some specifications. 
Table 9

Robustness Check: Replacing TE with Policy Uncertainty Index and Crisis Dummy

\begin{tabular}{|c|c|c|}
\hline & 1 & 2 \\
\hline \multirow[t]{2}{*}{ Short-term bond yield (2 year) } & $0.0849^{* * *}$ & $0.0832^{* * *}$ \\
\hline & $(9.334)$ & $(7.770)$ \\
\hline \multirow[t]{2}{*}{ Real GDP growth (y-o-y) [Consensus Forecast] } & $-0.3552^{* *}$ & $-0.3505^{* * *}$ \\
\hline & $(-2.749)$ & $(-2.868)$ \\
\hline \multirow[t]{2}{*}{ CPI inflation (y-o-y) [Consensus Forecast] } & $0.4378^{* *}$ & $0.3972^{* *}$ \\
\hline & $(2.273)$ & $(2.625)$ \\
\hline \multirow[t]{2}{*}{ Debt/GDP*100 [WEO projection, 5 year max] } & $0.0267^{* *}$ & $0.0271^{* *}$ \\
\hline & $(2.390)$ & $(2.388)$ \\
\hline \multirow[t]{2}{*}{ Domestic official debt share [lagged] } & $-0.0829^{* *}$ & $-0.0811^{* *}$ \\
\hline & $(-2.273)$ & $(-2.398)$ \\
\hline \multirow[t]{2}{*}{ Foreign debt share } & $-0.0647^{* * *}$ & \\
\hline & $(-3.657)$ & \\
\hline \multirow[t]{2}{*}{ Foreign official debt share } & & $-0.0551^{* *}$ \\
\hline & & $(-2.308)$ \\
\hline \multirow[t]{2}{*}{ Foreign non-official (bank and non-bank) debt share } & & $-0.0688^{* * *}$ \\
\hline & & $(-3.700)$ \\
\hline \multirow[t]{2}{*}{ Crisis dummy (=1 for 2008Q3 onwards) } & $-0.5419^{*}$ & $-0.5965^{*}$ \\
\hline & $(-1.859)$ & $(-1.804)$ \\
\hline \multirow[t]{2}{*}{ Policy uncertainty index (Bloom, 2009; Baker et al, 2013) } & $-0.0061^{* * *}$ & $-0.0063^{* * *}$ \\
\hline & $(-3.521)$ & $(-3.472)$ \\
\hline \multirow[t]{2}{*}{ Constant } & $5.4983^{* * *}$ & $5.5873^{* * *}$ \\
\hline & $(5.400)$ & $(5.778)$ \\
\hline Observations & 792 & 792 \\
\hline R-squared & 0.721 & 0.722 \\
\hline Number of countries & 22 & 22 \\
\hline R-square adjusted & 0.718 & 0.719 \\
\hline R-square overall & 0.230 & 0.215 \\
\hline
\end{tabular}

Note: The dependent variable is the nominal long-term bond yield (10 year). Estimations are performed using the fixed effects estimator. Robust t-statistics are in parentheses. $* * * * *$, and $*$ denote significance at 1,5 , and 10 percent level, respectively.

Table 10

Correlation Matrix of Independent Variables

\begin{tabular}{|c|c|c|c|c|c|c|c|c|}
\hline & $\begin{array}{c}\text { Long-term } \\
\text { bond yield } \\
\text { (2 years) }\end{array}$ & $\begin{array}{c}\text { Real } \\
\text { GDP } \\
\text { growth }\end{array}$ & $\begin{array}{c}\text { CPI } \\
\text { inflation }\end{array}$ & $\begin{array}{c}\text { Debt to } \\
\text { GDP } \\
\text { ratio }\end{array}$ & $\begin{array}{c}\text { Domestic } \\
\text { official debt } \\
\text { share } \\
\end{array}$ & $\begin{array}{c}\text { Foreign } \\
\text { debt } \\
\text { share }\end{array}$ & $\begin{array}{c}\text { Foreign } \\
\text { official } \\
\text { debt share } \\
\end{array}$ & $\begin{array}{c}\text { Foreign } \\
\text { non-official } \\
\text { debt share } \\
\end{array}$ \\
\hline $\begin{array}{l}\text { Long-term bond } \\
\text { yield ( } 2 \text { years) }\end{array}$ & 1.00 & & & & & & & \\
\hline Real GDP growth & -0.27 & 1.00 & & & & & & \\
\hline CPI inflation & -0.01 & 0.48 & 1.00 & & & & & \\
\hline Debt to GDP ratio & 0.15 & -0.43 & -0.55 & 1.00 & & & & \\
\hline $\begin{array}{l}\text { Domestic official } \\
\text { debt share }\end{array}$ & 0.03 & 0.09 & 0.15 & 0.20 & 1.00 & & & \\
\hline $\begin{array}{l}\text { Foreign official } \\
\text { debt share }\end{array}$ & -0.04 & -0.20 & 0.08 & 0.00 & -0.28 & 1.00 & & \\
\hline Foreign debt share & 0.01 & -0.11 & 0.03 & -0.08 & -0.14 & 0.44 & 1.00 & \\
\hline $\begin{array}{l}\text { Foreign non-official } \\
\text { debt share }\end{array}$ & -0.04 & -0.17 & 0.08 & 0.04 & -0.23 & 0.86 & -0.09 & 1.00 \\
\hline
\end{tabular}


Table 11

Granger Causality Tests for Individual Countries

\begin{tabular}{lcc}
\hline \hline United States & $\begin{array}{c}\text { Foreign investor base does not } \\
\text { cause interest rates? }\end{array}$ & $\begin{array}{c}\text { Interest rates do not cause foreign } \\
\text { investor base? }\end{array}$ \\
\hline United Kingdom & 0.00 & 0.12 \\
Austria & 0.12 & 0.67 \\
Belgium & 0.07 & 0.61 \\
Denmark & 0.03 & 0.53 \\
France & 0.01 & 0.35 \\
Germany & 0.47 & 0.89 \\
Italy & 0.44 & 0.74 \\
Netherlands & 0.03 & 0.01 \\
Sweden & 0.77 & 0.07 \\
Switzerland & 0.86 & 0.04 \\
Canada & 0.14 & 0.10 \\
Japan & 0.04 & 0.26 \\
Finland & 0.02 & 0.78 \\
Greece & 0.00 & 0.62 \\
Ireland & 0.03 & 0.01 \\
Portugal & 0.96 & 0.00 \\
Spain & 0.03 & 0.00 \\
Australia & 0.26 & 0.15 \\
New Zealand & 0.00 & 0.74 \\
Korea & 0.00 & 0.35 \\
Czech Republic & 0.35 & 0.76 \\
\hline \hline
\end{tabular}

Note: Country-specific Granger causality tests were run using 2 lags. Reported are p-values. P-values below 0.05 (highlighted in red) indicate rejection of the hypothesis stated on top of the column at 5 percent confidence level.

\subsection{Quantile Regression}

The panel fixed effects regressions discussed above assume that the impact of the FIB variable on bond yields is the same across all countries. To relax this assumption, we also estimate specification (1) using quantile regression. The quantile regression explicitly allows the impact of the FIB variable to vary across different quantiles of bond yields. As shown in Figure 3, the impact of the FIB on bond yields remains negative and significantly different from zero across all quantiles of bond yields. However, the negative impact tends to be larger in the upper quantile (up to -0.07), suggesting that the FIB has a stronger negative impact on bond yields when the level of interest rates is high. By contrast, the impact tends to be smaller in lower quantiles (up to -0.02), suggesting a smaller impact of FIB on bond yields when the level of interest rates is low.

These results are in line with models of creditor discrimination (Broner et al., 2013). In these models, creditor discrimination arises because, in turbulent times, sovereign debt offers a higher expected return to domestic creditors than to foreign ones. This provides incentives for domestic purchases of debt. In the context of recent developments, these results suggest that the recent outflow of foreign investment from the periphery countries may have had a larger impact on bond yields than the "safe haven" inflow of foreign funds to core AEs. 
Figure 3

Quantile regression: coefficient of the foreign investor base variable

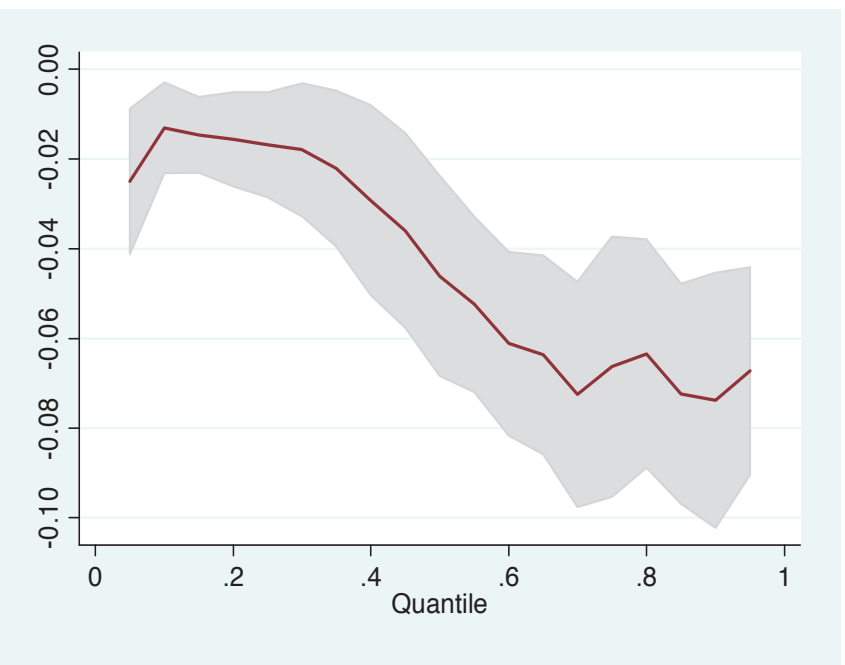

\subsection{Assessing the Impact of Changes in the Foreign Investor Base}

In this section, we assess the contribution of the FIB on bond yields, drawing on the results of the regression analysis.

Our regression results suggest that a 1 percentage point increase in the share of government debt held by foreigners is associated with a reduction in 10-year bond yields of about 8 basis points for a panel of 22 advanced economies. The impact remains qualitatively unchanged (within a range of 6.5 to 10.4 basis points) and statistically significant in all specifications. These estimates are in line with Warnock and Warnock (2009), whose corresponding estimate would be around 7 basis points for the United States. ${ }^{18}$ At the same time, they are somewhat higher than Andritzky (2012), whose estimates are around 6 basis points for euro area countries and 3-4 basis points for non-euro G-20 advanced economies.

Table 12 translates these estimates into contributions of the FIB to the changes in the longterm bond yields of major core and periphery countries. It shows that foreign inflows to bond markets may have reduced long-term rates by 35-60 basis points in the United States, 20-30 basis points in the United Kingdom, and 40-65 basis points in Germany since 2007. In contrast, foreign outflows from Italy and Spanish government bonds may have raised long-term yields by 40-70 and $110-180$ basis points in these countries, respectively.

Table 12

Impact of Foreign Investor Base (FIB) on Government Bond Yields, 2008-12

\begin{tabular}{lccccc}
\hline \hline \multirow{2}{*}{ Country } & $\begin{array}{c}\text { Change in foreign ownership } \\
\text { of government debt 1/ }\end{array}$ & \multicolumn{2}{c}{$\begin{array}{c}\text { Coefficient of foreign } \\
\text { Investor base }\end{array}$} & \multicolumn{2}{c}{$\begin{array}{c}\text { Contribution to change } \\
\text { in yields (bps) 1/ }\end{array}$} \\
\cline { 2 - 6 } (in percentage points) & Low & High & Low & High \\
\hline Germany & 6.1 & -0.065 & -0.104 & -40 & -64 \\
Italy & -6.8 & -0.065 & -0.104 & 44 & 71 \\
Spain & -17.1 & -0.065 & -0.104 & 110 & 178 \\
United Kingdom & 3.1 & -0.065 & -0.104 & -20 & -33 \\
United States & 5.4 & -0.065 & -0.104 & -35 & -57 \\
\hline \hline
\end{tabular}

Note: * change in ownership from end-2007 to end-2012.

18 Warnock and Warnock (2009) find that foreign flows into the U.S. Treasury market in the amount of 1 percent of GDP are associated with a 19 basis point reduction in long-term rates. This would correspond to a 2.7 percentage point increase in foreign ownership of U.S. Treasuries, based on figures from 2005 when their study ended. 
The implication of these estimates is that "flight to safety" flows in the form of foreign purchases of U.S., U.K., and German bonds after the global financial crisis may have made a substantial contribution to the decline in long-term interest rates in these countries. At the same time, foreign outflows from periphery countries can explain a substantial amount of the rise in their bond yields, in addition to the deterioration in their macroeconomic fundamentals immediately after the crisis.

Put differently, under a scenario in which the FIB normalizes to its pre-crisis level at end2007 , long-term bond yields may rise by $20-65$ basis points in major core economies and decline by $40-180$ basis points in major periphery countries. These are substantial amounts and highlight the important role of foreign investors in determining long-term bond yields even as the macroeconomic environment normalizes.

\section{CONCLUSIONS}

This paper analyzes the impact of the foreign investor flows on sovereign bond yields of 22 AEs. Our analysis suggests that an increase in foreign ownership is associated with a statistically and economically significant decline in long-term bond yields. In particular, we find that a 1 percentage point increase in the share of government debt held by non-residents can account for a 6-10 basis point decrease in 10-year government bond yields across advanced economies, controlling for other determinants for interest rates. This result is consistent with the "conundrum" phenomenon highlighted by U.S. policymakers in the early 2000s.

Moreover, country-specific Granger causality tests suggest that, for the vast majority of countries, the causality runs from foreign investor base to bond yields, and not vice versa. Exceptions are Greece, Ireland, Italy, and Portugal, i.e. only some of the periphery countries (or 4 out of 22 countries in the sample). For these countries, Granger causality tests suggest that foreign investors may have reacted to rising bond yields instead.

Overall, our results suggest that changes in the foreign investor base for sovereign debt can have economically and statistically significant effects on sovereign bond yields, independent of other standard macroeconomic determinants of bond yields.

\section{Acknowledgements}

The authors would like to thank to Luc Everaert, Abdelhak Senhadji, Ali Abbas, Ruchir Agarwal, Jochen Andritzky, Sergei Antoshin, Andrij Blokhin, Francesco Columba, Heiko Hesse, Bradley Jones, Luc Laeven, Prachi Mishra, Sergejs Saksonovs, Tahsin Saadi Sedik, Anita Tuladhar, and an anonymous referee for helpful comments and discussion.

\section{References}

Acharya, V. and Steffen, S. (2013), "The Greatest Carry Trade Ever? Understanding Eurozone Bank Risks" NBER Working Paper No. 19039, May 2013.

Andritzky, J. (2012). “Government Bonds and Their Investors: What Are the Facts and Do They Matter?", IMF Working Paper WP/12/158.

Arslanalp, S. and Tsuda, T. (2014). “Tracking Global Demand for Advanced Economy Sovereign Debt.” IMF Economic Review, Vol. 62, No. 3, International Monetary Fund, Washington, DC.

Baker, S., Bloom, N., and Davis, S. (2013). "Measuring Economic Policy Uncertainty", Stanford University Working Paper, available at: http://www.policyuncertainty.com/papers.html.

Bernanke, B. (2005). "The Global Saving Glut and the U.S. Current Account Deficit", The Homer Jones Lecture St. Louis, Missouri. 
Bernanke, B. (2013). "Long-Term Interest Rates", Remarks at the Annual Monetary and Macroeconomics Conference: The Past and Future of Monetary Policy, sponsored by the Federal Reserve Bank of San Francisco, San Francisco, California, March 1, 2013

Bernanke, B., Reinhart, V., Sack, B. (2004). "Monetary Policy Alternatives at the Zero Bound: An Empirical Assessment”, Brookings Papers on Economic Activity, 35: pp. 1-100.

Beltran, D., Kretchmer, M., Marquez, J., and Thomas, C. (2012). "Foreign Holdings of U.S. Treasuries and U.S. Treasury Yields", Federal Reserve Board, Washington D.C.

Bloom, N. (2009). "The Impact of Uncertainty Shocks”, Econometrica, 77 (3): pp. 623-85.

Borensztein, E., Cowan, K., Eichengreen, B., Panizza, U. (2008). "Prospects for Latin American Bond Markets: A Cross-Country View", in: Borensztein, Cowan, Eichengreen, Panizza (Eds.), Bond Markets in Latin America: On the Verge of a Big Bang? MIT Press, Cambridge, MA.

Broner, F., A. Erce, A. Martin, and Ventura, J. (2013). "Sovereign Debt Markets in Turbulent Times: Creditor Discrimination and Crowding-Out Effects," NBER Working Paper Series No. 19676.

Burger, J., and Warnock, F. (2006). "Local Currency Bond Markets", IMF Staff Papers, 53: pp. 133-146.

Caporale, G. and Williams, G. (2002). "Long-Term Nominal Interest Rates and Domestic Fundamentals", Review of Financial Economics, 15: pp. 370-413.

Claessens, S., Klingebiel, D., and Schmuckler, S. (2007). "Government Bonds in Domestic and Foreign Currency: The Role of Macroeconomic and Institutional Factors", Review of International Economics, 15: pp. $370-413$.

Correia-Nunes, J. and Stemitsiotis, L. (1995). "Budget Deficit and Interest Rates: Is There a Link? International Evidence", Oxford Bulletin of Economics and Statistics, 57(4): pp. 425-49.

Cottarelli, C. and Jaramillo, L. (2012). "Walking Hand in Hand: Fiscal Policy and Growth in Advanced Economies", IMF Working Paper WP/12/137.

Dell'Erba, S., Hausmann, R., and Panizza, U. (2013). "Debt Levels, Debt Composition, and Sovereign Spreads in Emerging and Advanced Economies", Oxford Review of Economic Policy (forthcoming).

Eichengreen, B., and Luengnaruemitchai, P. (2004). "Why Doesn't Asia Have Bigger Bond Markets?”, NBER Working Paper 10576. National Bureau of Economic Research, Cambridge, MA.

Engen, E. and Hubbard, G. (2004). "Federal Government Debt and Interest Rates", NBER Macroeconomic Annual, 19: pp. 83-138.

Forslund, K., Lima, L., and Panizza, U. (2011). "The Determinants of the Composition of Public Debt in Developing and Emerging Market Countries", Review of Development Finance, 1: pp. 207-222.

Hauner, D. and Kumar, M. (2006), "Fiscal Policy and Interest Rates--How Sustainable Is the New Economy?" IMF Working Paper No. 06/112, May 2006.

Hördahl, P., Tristani, O. and Vestin, D. (2006). “A Joint Econometric Model of Macroeconomic and Term-Structure Dynamics", Journal of Econometrics, 131 (1-2): pp. 405-444.

Ichiue, H. and Shimizu, Y. (2012). "Determinants of Long-term Yields: A Panel Data Analysis of Major Countries and Decomposition of Yields of Japan and the U.S.", Bank of Japan Working Paper, No. 12-E 7.

IMF (2011). Global Financial Stability Report, October 2011, IMF, Washington D.C.

IMF (2012a). Fiscal Monitor, October 2012, IMF, Washington D.C.

IMF (2012b). Global Financial Stability Report, October 2012, IMF, Washington D.C.

IMF (2013a). "Unconventional Monetary Policies-Recent Experience and Prospects," April 2013, IMF, Washington D.C.

IMF (2013b). "Staff Guidance Note for Public Debt Sustainability Analysis in Market-Access Countries,” May 2013, IMF, Washington D.C. (available at: http://www.imf.org/external/pubs/ft/dsa/mac.htm).

IMF (2013c). Fiscal Monitor, April 2013, IMF, Washington D.C.

Joyce, M., Lasaosa, A., Stevens, I., and Tong, M. (2011). "The Financial Market Impact of Quantitative Easing in the United Kingdom,” International Journal of Central Banking, 7(3): pp. 113-161.

Jaramillo, L., and Zhang, Y. (2013). "Real Money Investors and Sovereign Bond Yields", IMF Working Paper No. 13/254, December 2013

Kaminska, I., Vayanos D., and Zinna, G. (2011) "Preferred-habitat investors and the US term structure of real rates", Bank of England Working Paper No. 435.

Krishnamurthy, A. and Vissing-Jorgensen, A. (2011). "The Effects of Quantitative Easing on Interest Rates," Brooking Papers on Economic Activity, 43(2): pp. 215-287.

Krishnamurthy, A., and Vissing-Jorgensen, A. (2012). “The Aggregate Demand for Treasury Debt," Journal of Political Economy, 2012, vol. 120, no. 2.

Kumar, M., and Baldacci E. (2010), "Fiscal Deficits, Public Debt, and Sovereign Bond Yields" IMF Working Paper No. 10/184, August 2010.

Lam, R. (2013). “What Would Happen to Long-Term Interest Rates in Japan Under “Abenomics”?" paper presented at the IMF Surveillance Meeting, April 30, Washington, D.C.

Laubach, T. (2009). "New Evidence on the Interest Rate Effects of Budget Deficits and Debt", Journal of European Economic Association, 7: pp. 858-85. 
Mehl, A. and Reynaud, J. (2010). "Risky Public Domestic Debt Composition in Emerging Economies", Journal of International Money and Finance, 29: pp. 1-18.

Panizza, U. (2008). "Domestic and External Public Debt in Developing Countries", UNCTAD Discussion Paper. United Nations Conference on Trade and Development, Geneva.

Peiris, S. (2010). “Foreign Participation in Emerging Markets' Local Currency Bond Markets”, IMF Working paper $\mathrm{WP} / 10 / 88$.

Poghosyan, T. (2012). "Long-Run and Short-Run Determinants of Sovereign Bond Yields in Advanced Economies" IMF Working Paper No. 12/271.

Rudebusch, G., Swanson, E., and Wu, T. (2006). "The Bond Yield "Conundrum« from a Macro-Finance Perspective«, Monetary and Economic Studies, 24(S1): pp. 83-109.

Ueda, K. (2012). "The Effectiveness of Non-traditional Monetary Policy Measures: the Case of the Bank of Japan," The Japanese Economic Review, 63(1): pp. 1-22.

Warnock F., and Warnock, V. (2009). "International Capital Flows and U.S. Interest Rates," Journal of International Money and Finance, 28(6): pp. 903-919. 